\title{
Implementasi Metode AHP Untuk Sistem Pendukung Keputusan Proses Kenaikan Jabatan Karyawan
}

\author{
Jeperson Hutahaean ${ }^{1 *}$, Wily Julitawaty ${ }^{2}$ \\ ${ }^{1}$ Program Studi Sistem Informasi, STMIK Royal Kisaran \\ ${ }^{2}$ Program Studi Akutansi, STIE Professional Manajemen College Indonesia \\ Email: ${ }^{1 *}$ jepersonhutahaean@gmail.com
}

\begin{abstract}
Promotion or promotion is a transfer that increases the authority and responsibility of employees to higher positions within the organization so that the obligations, both status and income are greater. Almost all employees want to get a promotion. This research discusses finding the best solution to help take the decision to increase employee positions at PT. Prudential uses the Analitycal Hierarchy Process method to help determine the preferred priorities of various alternatives. This method was chosen because it is able to select the best candidates from a number of existing employees to occupy available positions based on predetermined criteria. Research is conducted by looking for weight values for each attribute, such as examples are aspects of intellectual capacity, aspects of work attitudes, and behavioral aspects, then carried out a perankingan process that will determine the optimal alternative, namely the promotion of employee positions. As a result of the application of the AHP method in this study, the value of the determination of the promotion of employee promotion 0 - 6 was declared unfit to be promoted and if the value is greater than 6, then the employee is declared worthy to be promoted to his position.
\end{abstract}

Keywords: SPK, Promotion, Employee, AHP

\begin{abstract}
ABSTRAK
Kenaikan jabatan atau promosi jabatan adalah perpindahan yang memperbesar wewenang dan tanggung jawab karyawan ke jabatan yang lebih tinggi di dalam organisasi sehingga kewajiban, baik status dan penghasilannya semakin besar. Hampir semua karyawan mendambakan untuk mendapatkan promosi jabatan tersebut. Penelitian ini membahas tentang mencari solusi terbaik untuk membantu mengambil keputusan kenaikan jabatan karyawan di PT. Prudential menggunakan metode Analitycal Hierarchy Process untuk membantu menentukan prioritas pilihan dari berbagai alternatif. Metode ini dipilih karena mampu menyeleksi kandidat terbaik dari sejumlah karyawan yang ada untuk menduduki jabatan yang tersedia berdasarkan kriteria-kriteria yang telah ditentukan. Penelitian dilakukan dengan mencari nilai bobot untuk setiap atribut, seperti contoh adalah aspek kapasitas intelektual, aspek sikap kerja, dan aspek perilaku, kemudian dilakukan proses perankingan yang akan menentukan alternatif yang optimal, yaitu kenaikan jabatan karyawan. Hasil dari penerapan metode AHP pada penelitian ini, nilai ketetapan penentuan promosi kenaikan jabatan karyawan $0-6$ dinyatakan tidak layak untuk dipromosikan kenaikan jabatannya dan jika nilai lebih besar dari 6, maka karyawan dinyatakan layak untuk dipromosikan kenaikan jabatannya.
\end{abstract}

Kata Kunci: SPK, kenaikan Jabatan, Karyawan, AHP.

\section{Pendahuluan}

PT. Prudential adalah perusahaan yang bergerak di bidang asuransi jiwa dan dikaitkan dengan invenstasi (unit link) dirancang untuk memenuhi dan melengkapi kebutuhan nasabahnya, dalam setiap tahap kehidupan, mulai dari usia kerja, pernikahan, kelahiran anak, pendidikan anak, dan masa pensiun. Penelitian ini membahas tentang mencari solusi terbaik untuk membantu mengambil keputusan kenaikan jabatan pegawai di PT. Prudential menggunakan metode Analitycal Hierarchy Process. Metode ini dipilih karena mampu menyeleksi kandidat terbaik dari sejumlah pegawai yang ada, dalam hal ini kandidat yang dimaksudkan yaitu karyawan yang berhak menduduki jabatan yang tersedia berdasarkan kriteriakriteria yang telah ditentukan. Penelitian dilakukan dengan mencari nilai bobot untuk setiap atribut, seperti contoh adalah aspek kapasitas intelektual, aspek sikap 
kerja, dan aspek perilaku, kemudian dilakukan proses metode untuk mencari alternatif solusinya, beberapa perankingan yang akan menentukan alternatif yang metode yang dipakai dalam Sistem Pendukung optimal, yaitu kenaikan jabatan karyawan.

Analisis jabatan merupakan cara yang sistematis yang mampu mengindentifikasi serta menganalisa persyaratan apa saja yang diperlukan dalam sebuah diuraikan, maka tujuan dari penelitian ini adalah pekerjaan serta personel yang dibutuhkan dalam suatu mengetahui proses kenaikan jabatan karyawan, pekerjaan sehingga sumber daya manusia yang dipilih membangun sistem pendukung keputusan kenaikan mampu melaksanakan pekerjaan itu dengan baik. Dari jabatan karyawan berdasarkan kinerja pada PT. hasil analisis jabatan tersebut maka organisasi akan Prudential dengan Metode AHP dan mempermudah mampu menentukan karateristik seperti apa yang harus pimpinan dalam menentukan kenaikan jabatan dimiliki calon pegawai sebelum menduduki sebuah karyawan.

jabatan, yang outputnya berupa spesifikasi jabatan dan deskripsi pekerjaan. Analisis jabatan sebagai dasar penilaian kinerja bagi pegawai. Penilaian kinerja ini 2 lazimnya dilakukan setiap tahun sekali namun demikian semua kembali kepada kebijakan sebuah organisasi itu sendiri[1].

Kenaikan jabatan karyawan dalam suatu organisasi ataupun instansi baik dalam pemerintahan terstruktur. Pada dasarnya konsep sistem pendukung maupun non pemerintahan (swasta) adalah suatu keputusan hanyalah sebatas pada kegiatan membantu penghargaan. Seseorang yang menerima promosi para manajer melakukan penelitian serta menggantikan jabatan harus memiliki kualifikasi yang baik dibanding posisi serta peran manajer[3].

kandidat-kandidat yang lain. Kenaikan jabatan atau promosi jabatan adalah perpindahan yang memperbesar wewenang dan tanggung jawab karyawan ke jabatan yang lebih tinggi di dalam organisasi sehingga kewajiban, baik status dan penghasilannya semakin besar. Hampir semua karyawan mendambakan untuk mendapatkan promosi jabatan tersebut. Karena pada dasarnya semua karyawan menginginkan kehidupan yang lebih baik dari sebelumnya, pendapatan yang lebih tinggi dan juga status sosial[2].

Oleh karena itu pemimpin harus menyadari pentingnya kenaikan jabatan dalam peningkatan produktivitas yang harus dipertimbangkan secra objektif. Jika pemimpin telah menyadari dan 1 mempertimbangkan, maka perusahaan akan terhindar dari masalah-masalah yang menghambat peningkatan keluaran dan dapat merugikan perusahaan seperti : ketidak puasan karyawan, adanya keluhan, tidak adanya semangat kerja, menurunnya disiplin kerja, tingkat absensi yang tinggi atau bahkan masalah- 2 maslah pemogokan kerja

Sistem Pendukung Keputusan merupakan bagian dari sistem informasi yang berbasis komputer. Terdapat beberapa tahapan dalam sistem pendukung keputusan yaitu mendefinisikan masalah, pengumpulan data yang relevan dan sesuai, pengolahan data menjadi informasi, dan menentukan alternatif solusi. Sistem ini membantu mendukung dalam pengambilan keputusan pada seseorang dan organisasi baik perusahaan maupun instansi.

Sistem Pendukung Keputusan dapat memberikan alternatif solusi bila seseorang atau sekelompok orang sulit dalam menentukan keputusan yang tepat dan sesuai. Sistem Pendukung Keputusan memerlukan

Metode Analytic Hierarchy Process (AHP) adalah metode keputusan multikriteria untuk pemecahan masalah yang kompleks atau rumit, dalam situasi takterstruktur menjadi bagian-bagian yang kemudian dibentuk menjadi hierarki fungsional atau terstruktur network untuk menampilkan masalah yang akan dipecahkan dan kemudian membangun urutan prioritas untuk alternative melalui perbandingan berpasangan alternative yang ada berdasarkan penilaian dari pembuat keputusan terhadap sistem Analytical Hierarki Proses[4].

Pada dasarnya, prosedur atau langkah-langkah dalam metode meliputi:

Mendefenisikan masalah dan menentukan solusi yang diinginkan, lalu menyusun hierarki dari permasalahan yang dihadapi. Penyusunan hierarki adalah dengan menetapkan tujuan yang merupakan sasaran sistem secara keseluruhan pada level teratas.

2. Menentukan prioritas elemen

a. Langkah pertama dalam menentukan prioritas elemen adalah membuat perbandingan pasangan, yaitu membandingkan elemen secara berpasangan sesuai kriteria yang diberikan.

b. Matriks perbandingan berpasangan diisi menggunakan bilangan untuk mempresentasikan kepentingan relatif dari suatu elemen terhadap elemen yang lainnya.

3. Sintesis

Pertimbangan-pertimbangan terhadap perbandingan berpasangan disintesis untuk memperoleh keseluruhan prioritas. Hal-hal yang dilakukan dalam hal ini adalah: 
a. Menjumlahkan nilai-nilai dari setiap kolom pada matriks

b. Membagi setiap nilai dari kolom dengan total dilakukan:

kolom yang bersangkutan untuk memperoleh normalisasi matriks

c. Menjumlahkan nilai-nilai dari setiap baris dan membaginya dengan jumlah elemen untuk mendapatkan nilai rata-rata.

4. Mengukur konsistensi

Dalam pembuatan keputusan, penting untuk mengetahui seberapa baik konsistensi yang ada karena kita tidak menginginkan keputusan berdasarkan pertimbangan dengan konsistensi yang rendah. Hal-hal yang dilakukan dalam hal ini adalah:

a. Kalikan setiap nilai pada kolom pertama dengan prioritas relatif elemen pertama, nilai pada kolom kedua dengan prioritas relatif elemen kedua, dan seterusnya.

b. Jumlahkan setiap baris

c. Hasil dari penjumlahan baris dibagi dengan elemen prioritas relatif yang bersangkutan.

d. Jumlahkan hasil bagi diatas dengan banyaknya elemen yang ada, hasilnya disebuat $\lambda$ maks

Hitung Consistency index $(C I)$ dengan rumus:

$C I=(\lambda$ maks $-\mathrm{n}) / \mathrm{n}$

Dimana $n=$ banyaknya elemen

5. Hitung Rasio Konsistensi / Consistency Ratio

$(C R)$ dengan rumus:

$C R=C I / R C$

Dimana $C R=$ Consistency Ratio

$C I=$ Consistency Index

$I R=$ Index Random Consistency

6. Memeriksa konsistensi hierarki. Jika nilainya lebih dari $10 \%$, maka penilaian data judgement harus diperbaiki. Namun, jika rasio konsistensi $(C R / I R)$ kurang atau sama dengan 0,1 , maka hasil perhitungan bisa dinyatakan benar.

\section{Hasil dan Pembahasan}

Pedoman yang dijadikan dasar untuk kenaikan jabatan karyawan diantaranya adalah: pengalaman, kecakapan dan juga kombinasi kecakapan dan pengalaman kerja.

\subsection{Analisis Metode Analitycal Hierarkhi Process} (AHP)

AHP merupakan metode untuk memecahkan suatu situasi yang komplek tidak terstruktur kedalam beberapa komponen dalam susunan yang hierarkhi, dengan member nilai subjektif tentang pentingnya setiap variable secara relative, dan menetapkan variable mana yang memiliki prioritas paling tinggi guna mempengaruhi hasil pada situasi tersebut.

Ada beberapa kriteria yang dipertimbangkan oleh perusahaan beserta penilaiannya adalah :

1. Kehadiran : baik, cukup, kurang

2. Pencapaian Kerja : baik, cukup, kurang

3. Pengalaman: baik, cukup, kurang

4. Perilaku : baik, cukup, kurang kolom lama.

Berikut range nilai ketentuan tiap-tiap kriteria yang digunakan dalam pengambilan keputusan yang

Tabel 1. Nilai Perhitungan Kriteria
\begin{tabular}{|l|c|c|c|}
\hline \multicolumn{1}{|c|}{ Kriteria } & Baik & Cukup & Kurang \\
\hline Kehadiran & $0-3$ & $4-8$ & $>8$ \\
\hline $\begin{array}{l}\text { Pencapaian } \\
\text { Kerja }\end{array}$ & $>80 \%$ & $56 \%-79 \%$ & $<55 \%$ \\
\hline Pengalaman & $\begin{array}{l}>2,9 \\
\text { tahun }\end{array}$ & $1,5-3$ tahun & $<1,5$ tahun \\
\hline Perilaku & $>=4$ & $2-3$ & $<2$ \\
\hline
\end{tabular}

\subsection{Menentukan Prioritas Kriteria}

Langkah yang harus dilakukan dalam menentukan prioritas kriteria adalah sebagai berikut :

1. Membuat matriks perbandingan berpasangan Pada tahap ini dilakukan penilaian perbandingan antara satu kriteria dengan kriteria yang lain.

Tabel 2. Matriks Perbandingan Berpasangan

\begin{tabular}{|l|c|c|c|c|}
\hline & Kehadiran & $\begin{array}{c}\text { Pencapaian } \\
\text { Kerja }\end{array}$ & Pengalaman & Perilaku \\
\hline Kehadiran & 1 & 2 & 3 & 4 \\
\hline $\begin{array}{l}\text { Pencapaian } \\
\text { Kerja }\end{array}$ & 0.5 & 1 & 5 & 4 \\
\hline Pengalaman & 0.33 & 0.2 & 1 & 2 \\
\hline Perilaku & 0.25 & 0.25 & 0.5 & 1 \\
\hline Jumlah & $\mathbf{2 . 0 8}$ & $\mathbf{3 . 4 5}$ & $\mathbf{9 . 5}$ & $\mathbf{1 1}$ \\
\hline
\end{tabular}

Angka 1 pada kolom kehadiran baris kedisiplinan menggambarkan tingkat kepentingan yang sama antara kedisiplinan dengan kehadiran, sedangkan angka 2 pada kolom pencapaian kerja baris kehadiran menunjukkan pencapaian kerja sedikit lebih penting dibandingkan dengan kehadiran. Angka 0,5 pada kolom kehadiran baris pencapaian kerja merupakan hasil perhitungan 1/nilai pada kolom pencapain kerja baris kehadiran. Angka-angka yang lain diperoleh dengan cara yang sama.

Jumlah pada kehadiran $=1+0,5+0,33+0,25=\mathbf{2 , 0 8}$

Jumlah pada kolom pencapaian $=2+1+0,2+0,25=\mathbf{3 , 4 5}$

Jumlah pada kolom pengalaman $=3+5+1+0,5=\mathbf{9 , 5}$

Jumlah pada kolom perilaku $=4+4+2+1=\mathbf{1 1}$

2. Membuat matriks nilai kriteria

Matriks ini diperoleh dengan rumus: nilai baris kolom baru $=$ nilai baris - kolom lama/ jumlah masing

\begin{tabular}{|l|c|c|c|c|c|c|}
\hline & $\begin{array}{c}\text { Kehadi } \\
\text { ran }\end{array}$ & $\begin{array}{c}\text { Penca } \\
\text { paian }\end{array}$ & $\begin{array}{c}\text { Penga } \\
\text { laman }\end{array}$ & $\begin{array}{c}\text { Perila } \\
\text { ku }\end{array}$ & Jumlah & $\begin{array}{c}\text { Prior } \\
\text { itas }\end{array}$ \\
\hline $\begin{array}{l}\text { Kehad } \\
\text { iran }\end{array}$ & 0.48 & 0.58 & 0.32 & 0.36 & 1.74 & 0.43 \\
\hline $\begin{array}{l}\text { Penca } \\
\text { paian }\end{array}$ & 0.24 & 0.29 & 0.53 & 0.36 & 1.42 & 0.35 \\
\hline $\begin{array}{l}\text { Pengal } \\
\text { aman }\end{array}$ & 0.16 & 0.06 & 0.11 & 0.18 & 0.51 & 0.13 \\
\hline $\begin{array}{l}\text { Perilak } \\
\mathrm{u}\end{array}$ & 0.12 & 0.07 & 0.05 & 0.09 & 0.34 & 0.08 \\
\hline
\end{tabular}


Nilai 0,48 pada kolom kehadiran baris kehadiran

Kolom jumlah perbaris di peroleh dari kolom table 3, di peroleh dari nilai kolom kehadiran baris pada tabel 4, sedangkan kolom prioritas di peroleh pada kehadiran pada tabel 2 dibagi jumlah kolom kehadiran tabel 3. Dari tabel 5 di peroleh nilai sebagai berikut: tabel 2 , dan seterusnya: $0,48 \Rightarrow 1 / 2,08 ; 0,24=>0,5 /$ Jumlah : 4,73+4,03+0,59+0,24 = 9,59 2,$08 ; 0,16=>0,33 / 2,08 ; 0,12=>0,25 / 2,08$ n (jumlah kriteria) : 4

Nilai kolom jumlah pada tabel 3 di peroleh dari ${ }^{\gamma}$ maks (jumlah/n) : 9,59/4 $=2,40$ penjumlahan pada setiap barisnya. Untuk hasil pertama, CI $((\gamma$ maks-n $) / n):(2,40-4) / 4=-0,40$ nilai 1,74 merupakan hasil penjumlahan dari CR (CI/IR(lihat tabel 2.2 daftar indeks random $0,48+0,58+0,32+0,36$ begitu selanjutnya. konsitensi) :

Nilai pada kolom prioritas di peroleh dari nilai Nilai IR pada table 2.2 dengan 4 kriteria $=0,90$ pada kolom jumlah dibagi dengan jumlah kriteria, Maka, $\mathrm{CR}=\mathrm{CI} / \mathrm{IR}$ dalam hal ini 4 kriteria.

$0,43 \Rightarrow 1,74 / 4 ; 0,35 \Rightarrow 1,42 / 4 ; 0,13 \Rightarrow 0,51 / 4$; $0,08=>0,34 / 4$

3. Membuat matriks penjumlahan setiap baris

Matriks ini dibuat dengan mengalikan nilai prioritas pada tabel 3 dengan matriks perbandingan berpasangan tabel 2. Hasil perhitungan disajikan dalam tabel 4.

Tabel 4. Matriks Penjumlahan Setiap Baris

\begin{tabular}{|l|c|c|c|c|c|}
\hline & $\begin{array}{c}\text { Kehadi } \\
\text { ran }\end{array}$ & $\begin{array}{c}\text { Pencap } \\
\text { aian }\end{array}$ & $\begin{array}{c}\text { Pengal } \\
\text { aman }\end{array}$ & $\begin{array}{c}\text { Perilak } \\
\mathrm{u}\end{array}$ & Jumlah \\
\hline $\begin{array}{l}\text { Kehadi } \\
\text { ran }\end{array}$ & 0.43 & 0.86 & 1.29 & 1.72 & 4.30 \\
\hline $\begin{array}{l}\text { Pencap } \\
\text { aian }\end{array}$ & 0.18 & 0.35 & 1.75 & 1.40 & 3.68 \\
\hline $\begin{array}{l}\text { Pengal } \\
\text { aman }\end{array}$ & 0.04 & 0.03 & 0.13 & 0.26 & 0.46 \\
\hline $\begin{array}{l}\text { Perilak } \\
\text { u }\end{array}$ & 0.02 & 0.02 & 0.04 & 0.08 & 0.16 \\
\hline
\end{tabular}

Nilai 0,43 pada baris kehadiran kolom kehadiran tabel 4 di peroleh dari prioritas baris kehadiran pada tabel $3(0,43)$ dikalikan dengan nilai baris kehadiran kolom kehadiran pada tabel 2 (1), dan seterusnya.

$0,43=>1 * 0,43$

$0,18=>0,5 * 0,43$

$0,04=>0,33 * 0,43$

$0,02=>0,25 * 0,43$

Kolom jumlah pada tabel 5 di peroleh dengan menjumlahkan nilai pada masing-masing baris pada tabel tersebut.

$$
\begin{aligned}
& 4,30=>0,43+0,86+1,29+1,72 \\
& 3,68=>0,18+0,35+1,75+1,40 \\
& 0,46=>0,04+0,03+0,13+0,04 \\
& 0,16=>0,02+0,02+0,04+0,08
\end{aligned}
$$

4. Perhitungan rasio konsistensi

Perhitungan ini digunakan untuk memastikan bahwa nilai rasio konsistensi $(\mathrm{CR})<=0,1$. Jika ternyata nilai CR lebih besar dari 0,1 maka matriks perbandingan berpasangan harus di perbaiki, untuk menghitung rasio konsistensi di buat tabel seperti terlihat tabel 5.

Tabel 5. Perhitungan Rasio Konsistensi

\begin{tabular}{|l|c|c|c|}
\hline & $\begin{array}{c}\text { Jumlah } \\
\text { perbaris }\end{array}$ & Prioritas & Hasil \\
\hline Kehadiran & 4.30 & 0.43 & 4.73 \\
\hline Pencapaian Kerja & 3.68 & 0.35 & 4.03 \\
\hline Pengalaman & 0.46 & 0.13 & 0.59 \\
\hline Perilaku & 0.16 & 0.08 & 0.24 \\
\hline
\end{tabular}

$$
\begin{aligned}
& =(-0,40) / 0,90 \\
& =\mathbf{- 0 , 4 4}
\end{aligned}
$$

Oleh karena itu $\mathrm{CR}<0,1$, maka rasio konsitensi dari perhitungan tersebut bisa diterima.

\subsection{Menentukan Prioritas Subkriteria}

Penghitungan subkriteria dilakukan terhadap subsub dari semua kriteria. Dalam hal ini, terdapat 4 kriteria yang berarti ada 4 perhitungan prioritas subkriteria.

1. Menentukan Penilaian Kriteria dan Alternatif

Kriteria dan alternative dilakukan dengan perbandingan berpasangan. Untuk berbagai persoalan,

\begin{tabular}{|c|c|}
\hline $\begin{array}{c}\text { Intensitas } \\
\text { Kepentingan }\end{array}$ & Keterangan \\
\hline 1 & Kedua elemen sama pentingnya \\
\hline 3 & $\begin{array}{l}\text { Elemen yang satu sedikit lebih penting } \\
\text { daripada elemen yang lainnya }\end{array}$ \\
\hline 5 & $\begin{array}{l}\text { Elemen yang satu lebih penting daripada } \\
\text { lainnya }\end{array}$ \\
\hline 7 & $\begin{array}{l}\text { Satu elemen jelas lebih mutlak penting } \\
\text { daripada elemen lainnya }\end{array}$ \\
\hline 9 & $\begin{array}{l}\text { Satu elemen mutlak penting daripada elemen } \\
\text { lainnya }\end{array}$ \\
\hline $2,4,6,8$ & $\begin{array}{l}\text { Nilai-nilai antara dua nilai pertimbangan yang } \\
\text { berdekatan }\end{array}$ \\
\hline Kebalikan & $\begin{array}{l}\text { Jika aktivitas } \mathrm{i} \text { mendapat satu angka } \\
\text { dibandingkan dengan aktivitas i, maka i } \\
\text { memiliki nilai kebalikkannya dibandingkan } \\
\text { dengan i }\end{array}$ \\
\hline
\end{tabular}
skala 1 sampai 9 adalah skala terbaik untuk mengekspresikan pendapat. Nilai dan definisi pendapat kualitatif dari skala perbandingan Saaty bisa diukur menggunakan table analisis seperti ditunjukkan pada tabel berikut :

2. Menghitung prioritas subkriteria dari kriteria kehadiran

Langkah-langkah yang dilakukan untuk menghitung prioritas subkriteria dari kriteria jumlah nilai adalah sebagai berikut :

a. Membuat matriks perbandingan berpasangan Tabel 8. Matriks Pebandingan Berpasangan Kriteria Kehadiran

\begin{tabular}{|l|c|c|c|}
\hline & Baik & Cukup & Kurang \\
\hline Baik & 1 & 3 & 5 \\
\hline Cukup & 0,33 & 1 & 3 \\
\hline Kurang & 0,2 & 0,33 & 1 \\
\hline & $\mathbf{1 , 5 3}$ & $\mathbf{4 , 3 3}$ & $\mathbf{9}$ \\
\hline
\end{tabular}


Jumlah pada kolom baik $=1+0,33+0,2=\mathbf{1 , 5 3}$

Jumlah pada kolom cukup $=3+1+0,33=\mathbf{4 , 3 3}$

Jumlah pada kolom kurang $=5+3+1=9$

b. Membuat matriks nilai kriteria

Tabel 9. Matriks Nilai Kriteria Kehadiran

\begin{tabular}{|l|c|c|c|c|c|}
\hline & Baik & Cukup & Kurang & $\begin{array}{c}\text { Priorit } \\
\text { as }\end{array}$ & $\begin{array}{c}\text { Prioritas } \\
\text { Subkriteria }\end{array}$ \\
\hline Baik & 0.65 & 0.69 & 0.56 & 0.63 & 1 \\
\hline Cukup & 0.22 & 0.23 & 0.33 & 0.26 & 0.41 \\
\hline Kurang & 0.13 & 0.08 & 0.11 & 0.11 & 0.17 \\
\hline
\end{tabular}

Nilai pada kolom prioritas subkriteria diperoleh dari nilai prioritas pada baris tersebut dengan nilai tertinggi pada kolom prioritas.

$0,65 \Rightarrow 1 / 1,53$

$0,22 \Rightarrow 0,33 / 1,53$

$0,13=>0,33 / 1,53$

Prioritas : $0.63=>(0,65+0,69+0,56) / 3$

Prioritas Subkriteria : $1=>0,63 / 0,63$

c. Menentukan matriks penjumlahan setiap baris Tabel 10. Matriks Penjumlahan Setiap Baris Kriteria Kehadiran

\begin{tabular}{|l|c|c|c|c|}
\hline & Baik & Cukup & Kurang & Jumlah \\
\hline Baik & 0,63 & 0,78 & 0,53 & 1,94 \\
\hline Cukup & 0,21 & 0,26 & 0,32 & 0,79 \\
\hline Kurang & 0,13 & 0,09 & 0,11 & 0,32 \\
\hline
\end{tabular}

$0,63 \Rightarrow 1 * 0,63 ; 0,78=>3 * 0,26 ; 0,53 \Rightarrow 5 * 0,11$

d. Penghitungan rasio konsistensi

Penghitungan ini digunakan untuk memastikan bahwa nilai rasio konsitensi $(\mathrm{CR}) \quad<=0,1$. Untuk menghitung rasio konsistensi, dibuat tabel seperti yang terlihat pada tabel 11 .

Tabel 11 Penghitungan Rasio Konsistensi

\begin{tabular}{|c|c|c|c|}
\hline & Jumlah Perbaris & Prioritas & Hasil \\
\hline Baik & 1.94 & 0.63 & 2.57 \\
\hline Cukup & 0.79 & 0.26 & 1.05 \\
\hline Kurang & 0.32 & 0.11 & 0.43 \\
\hline
\end{tabular}

Dari tabel 11, diperoleh nilai-nilai sebagai berikut. Jumlah (jumlah dari nilai-nilai hasil): 2,57+1,05+0,42 = 4,05

n (jumlah kriteria): 3

${ }^{\gamma}$ maks (jumlah/n): 4,05 / $3=1,35$

CI $((\gamma$ maks-n $) / n)):(1,35-3) / 3=-0,55$

CR (CI/IR(lihat tabel 2.2)):

Nilai IR pada table 2.2 dengan 3 kriteria $=0,85$

Maka, $\mathrm{CR}=\mathrm{CI} / \mathrm{IR}$

$$
\begin{aligned}
& =(-0,55) / 0,85 \\
& =\mathbf{- 0 , 6 5}
\end{aligned}
$$

Oleh karena $\mathrm{CR}<0,1$, maka rasio konsistensi dari perhitungan tersebut bisa diterima.

Begitu juga seterusnya untuk proses perhitungan subkriteria pencapaian, pengalaman dan perilaku.

3.4 Menghitung Hasil
Prioritas hasil perhitungan pada langkah 1 dan 2 kemudahan dituangkan dalam matriks hasil yang terlihat dalam tabel 12 .

Tabel 12. Matriks Hasil

\begin{tabular}{|c|c|c|c|}
\hline Kehadiran & Pencapaian Kerja & Pengalaman & Perilaku \\
\hline 0,43 & 0,35 & 0,13 & 0,08 \\
\hline Baik & Baik & Baik & Baik \\
\hline 1 & 1 & 1 & 1 \\
\hline Cukup & Cukup & Cukup & Cukup \\
\hline 0,41 & 0,47 & 0,45 & 0,56 \\
\hline Kurang & Kurang & Kurang & Kurang \\
\hline 0,17 & 0,22 & 0,2 & 0,10 \\
\hline
\end{tabular}

Nilai $(0,43),(0,35),(0,13),(0,08)$ diambil dari prioritas kriteria.

Nilai $(1), \quad(0,41), \quad(0,17)$ diambil dari prioritas subkriteria kehadiran.

Nilai (1), $(0,47),(0,22)$ diambil dari prioritas subkriteria pencapaian kerja.

Nilai $(1),(0,45),(0,2)$ diambil dari prioritas subkriteria pengalaman.

Nilai (1), (0,56), $(0,10)$ diambil dari prioritas subkriteria perilaku.

Diberikan data nilai dari 3 orang karyawan, maka hasil akhirnya akan tampak dalam tabel 13

Tabel 13. Nilai Karyawan

\begin{tabular}{|l|c|c|c|c|}
\hline & Kehadiran & $\begin{array}{c}\text { Pencapaian } \\
\text { Kerja }\end{array}$ & Pengalaman & Perilaku \\
\hline Andi & Baik & Cukup & Baik & Baik \\
\hline Bayu & Baik & Kurang & Cukup & Cukup \\
\hline Chika & Cukup & Baik & Baik & Baik \\
\hline
\end{tabular}

Tabel 14. Hasil Akhir

\begin{tabular}{|l|c|c|c|c|c|c|}
\hline g & $\begin{array}{c}\text { Keha } \\
\text { diran }\end{array}$ & $\begin{array}{c}\text { Pencapai } \\
\text { an }\end{array}$ & $\begin{array}{c}\text { Pengal } \\
\text { aman }\end{array}$ & $\begin{array}{c}\text { Perilak } \\
\mathrm{u}\end{array}$ & Tot & $\begin{array}{c}\text { Total } \\
\text { Pembulata } \\
\mathrm{n}\end{array}$ \\
\hline Andi & 0,43 & 0,16 & 0,13 & 0,08 & 0,8 & 8,0 \\
\hline Bayu & 0,43 & 0,08 & 0,06 & 0,04 & 0,57 & 5,7 \\
\hline Chika & 0,18 & 0,35 & 0,13 & 0,08 & 0,74 & 7,4 \\
\hline
\end{tabular}

Nilai 0,43 pada kolom kehadiran baris Andi diperoleh dari nilai karyawan Andi untuk kehadiran, yaitu cukup dengan prioritas 1, dikalikan dengan prioritas kehadiran sebesar 0,43 begitu selanjutnya.

$0,43=>1 * 0,43$

$0,43 \Rightarrow 1 * 0,43$

$0,18=>0,41 * 0,43$

Kolom total di peroleh dari penjumlahan pada masing-masing barisnya.

$0,8=>0,43+0,16+0,13+0,08$

$0,57 \Rightarrow 0,43+0,08+0,06+0,04$

$0,74=>0,18+0,35+0,13+0,08$

Nilai kolom total pembulatan diperoleh dari perhitungan nilai kolom total dikalikan nilai 10 . Pada nilai total pembulatan inilah yang dipakai sebagai dasar untuk menentukan promosi kenaikan jabatan karyawan. Semakin besar nilai total pembulatan, karyawan tersebut akan semakin berhak untuk dipromosikan kenaikan jabatannya.

$8,0=>0,8 * 10$ 
$5,7=>0,57 * 10$

$7,4=>0,74 * 10$

Berdasarkan nilai ketetapan penentuan promosi kenaikan jabatan karyawan yang telah dibuat, nilai 0 6 dinyatakan tidak layak untuk dipromosikan kenaikan
jabatannya. Dan jika nilai lebih besar dari 6 , maka karyawan dinyatakan layak untuk dipromosikan kenaikan jabatannya.

Berikut adalah rancangan use case diagram yang akan penulis usulkan untuk memperbaharui rancangan prosedur yang lama

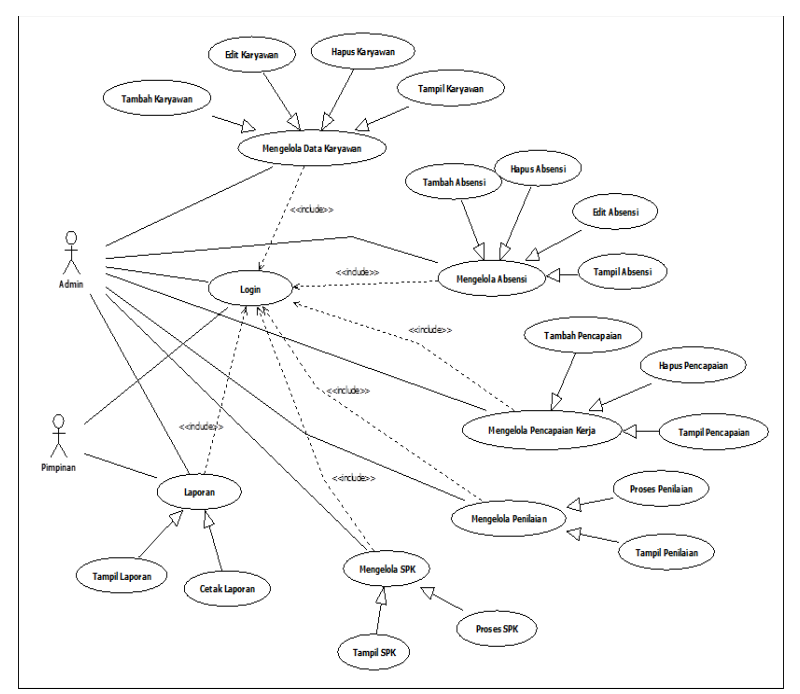

.Gambar 1. Usecase Diagram

3.4 Tampilan Awal Halaman Utama SPK Kenaikan Jabatan Karyawan PT. Prudential Kisaran.

Pada halaman utama sistem pendukung keputusan kenaikan jabatan karyawan PT. Prudential Kisaran ini berfungsi untuk menampilkan menu atau sub-sub menu pada sistem sesuai dengan hak akses sistem pengambilan keputusan PT. Prudential Kisaran. Berikut ini adalah tampilan halaman utama sistem pendukung keputusan kenaikan jabatan karyawan PT. Prudential Kisaran

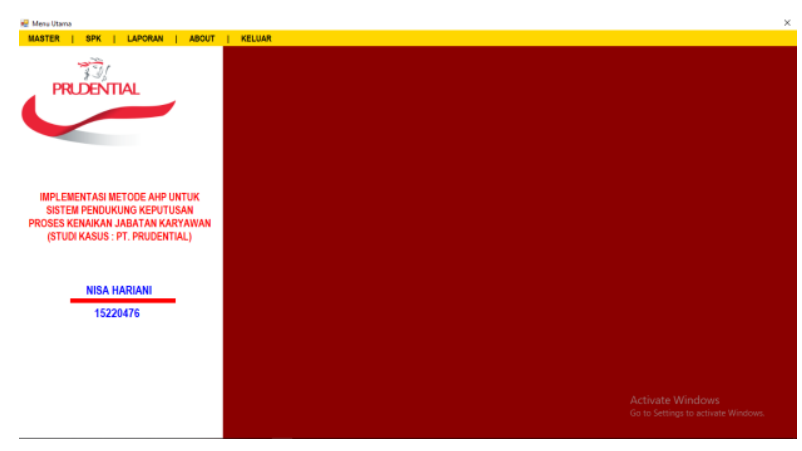

Gambar 2. Halaman Utama

Implementasi antarmuka halaman utama SPK kenaikan jabatan karyawan PT. Prudential Kisaran terdiri dari beberapa menu seperti master, SPK, Laporan, about dan keluar.
Pada menu master terdapat submenu data karyawan sebagai data alternatif yang akan dinilai. Pada halaman ini berisi form untuk penambahan, pengubahan, penghapusan, pencarian serta menampilkan seluruh data karyawan. Berikut ini adalah tampilan data karyawan

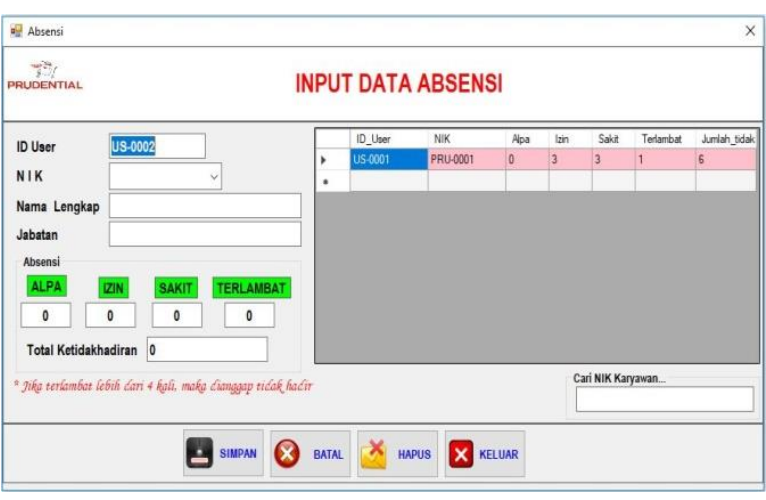

Gambar 3. Input Data Karyawan

Pada halaman absensi berisi form untuk melakukan penambahan, pengubahan, penghapusan, pencarian serta menampilkan data absensi karyawan. Berikut ini adalah tampilan data absensi.

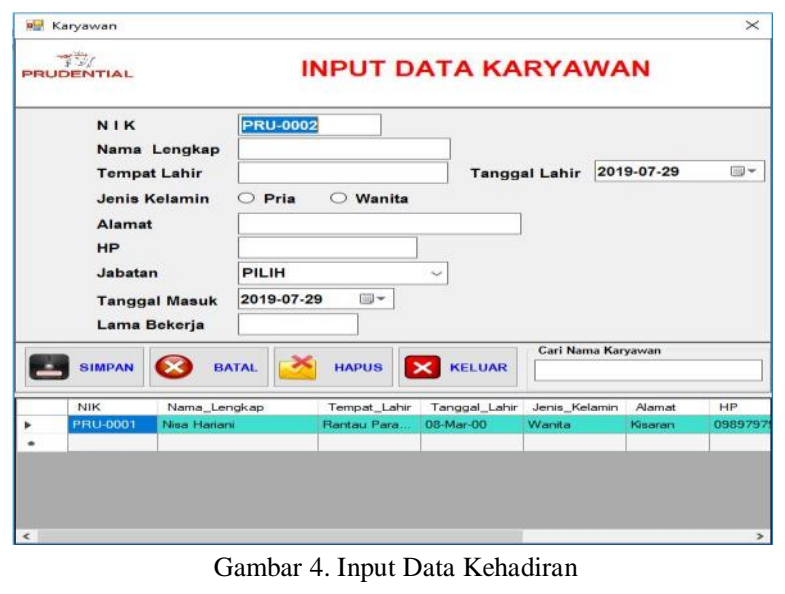

Pada halaman pencapaian berisi form untuk melakukan penambahan, pengubahan, penghapusan, pencarian serta menampilkan data pencapaian kerja karyawan. Berikut ini adalah tampilan data pencapaian kerja.

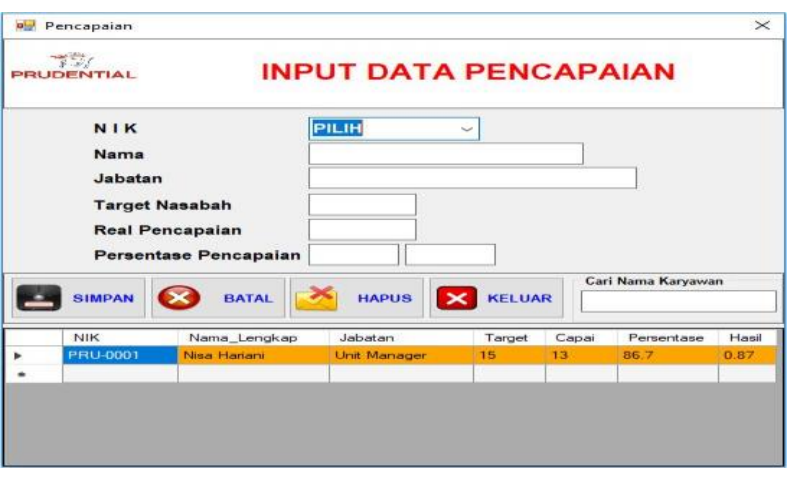

Gambar 5. Input Data Pencapaian 
Pada halaman pelaku berisi form untuk melakukan 4. Kesimpulan

penambahan, pengubahan, penghapusan, pencarian serta menampilkan data pelakukaryawan. Berikut ini adalah tampilan data prilaku.

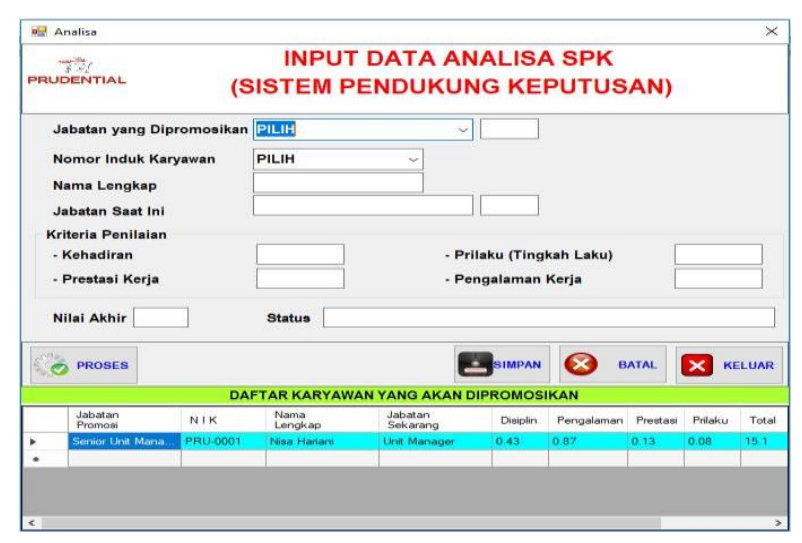

Gambar 6. Input Data Perilaku

Pada halaman SPK berisi form untuk melakukan penilaian terhadap data karyawan dan menampilkan [2] data karyawan yang telah dinilai dimana datanya dapat dilihat pada laporan. Berikut ini adalah tampilan data SPK.

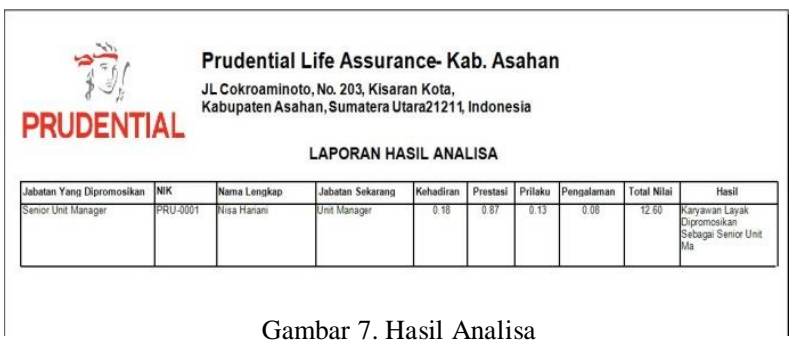

Berdasarkan implementasi dan pengujian yang telah dilakukan maka kesimpulan dari penelitian ini yaitu Sistem pendukung keputusan kenaikan jabatan karyawan pada PT. Prudential Kisaran yang dirancang telah memiliki nilai ketetapan dalam penentuan promosi jabatannya. Bagi karyawan yang memiliki nilai lebih kecil dari enam (6) maka karyawan dinyatakan tidak layak untuk dipromosikan kenaikkan jabatannya dan sebaliknya jika karyawan memiliki nilai lebih besar dari 6 maka karyawan dinyatakan layak untuk dipromosikan kenaikkan jabatannya. Dan untuk karyawan yang memiliki nilai paling tinggi yang akan mendapatkan promosi kenaikkan jabatannya.

\section{Referensi}

[1] S. Tanumihardjo, "Pengaruh Analisis Jabatan Terhadap Kinerja Pegawai (Studi Pada Sekretariat Daerah Pemerintah Kabupaten Malang)," J. Adm. Publik Mhs. Univ. Brawijaya, vol. 1, no. 6, pp. 1114-1122, 2013.

N. Angga, A. Pratamaputra, and N. Aeni, "Sistem Pendukung Keputusan Kenaikan Jabatan dengan Model AHP pada Biro Kepegawaian di Sekretariat Negara Republik Indonesia," Sist. Pendukung Keputusan Kenaikan Jab. dengan Model AHP pada Biro Kepegawai. di Sekr. Negara Republik Indones., vol. 3 , no. 1, pp. 1-10, 2010.

[3] A. A. Chamid, B. Surarso, and F. Farikhin, "Implementasi Metode AHP Dan Promethee Untuk Pemilihan Supplier," J. Sist. Inf. Bisnis, vol. 5, no. 2, pp. 128-136, 2015, doi: 10.21456/vol5iss2pp128-136.

[4] S. Saefudin and F. Cahyo, "Sistem Pendukung Keputusan Menentukan Pemberian Bonus Tahunan Pada Karyawan Menggunakan Metode Analytical Hierarchy Process (Ahp)," JSiI (Jurnal Sist. Informasi), vol. 6, no. 1, p. 54, 2019, doi: 10.30656/jsii.v6i1.1074. 